\title{
Study on the Sale Mode of New Electric Power
}

\author{
Yun-yan Li, Yuan-sheng Huang, Juan Chen
}

\author{
Department of Economic Management, North China Electric Power University, Baoding, China
}

Keywords: New electricity reform, Sale mode, SWOT analysis

\begin{abstract}
The electric power industry has the characteristics of huge investment asset specificity and scale economy. It determines the power market must focus on strengthening supervision, in order to ensure a healthy competitive relationship in the power industry. In the new electricity reform, around the new energy industry value chain and actively implement the external joint Multi Strategy, and quickly enhance the competitiveness and speed of development. In this paper, the power supply company as an example expounds the contents and trends of the new electricity reform combined with the power grid enterprise functions. SWOT analysis was carried out on the basis of the sale of electricity market reform and development situation proposed the strategy of new electricity reform under the background of the Power Grid Corp can be taken.
\end{abstract}

\section{Introduction}

Background. In February 2016, the National Energy Bureau issued "guidance on the development and utilization of renewable energy, on the establishment of the target guidance system clearly put forward," according to the 2020 non fossil energy accounts for the proportion of total primary energy consumption reached $15 \%$ in 2020 , in addition to special non fossil energy production enterprises, electric power enterprises of non hydro renewable energy generating capacity should reach the total generating capacity of more than $9 \%$ ". At this stage, the transmission and distribution reform, the sale of electricity side reforms, such as the construction of the reform of the trading center has not yet been an organic combination. Power grid corp still has monopoly advantages in the transmission and distribution business explore the power trading center has just started all these factors make the sale of electricity business is very difficult to carry out large-scale short term, more only to provide a direct power purchase service to users.

At the same time, the national energy board to expand the scale of direct power transactions in 2016, and strive to achieve the industrial electricity consumption of $30 \%$ in 2018 , then to achieve full liberalization of industrial power, and to achieve full liberalization of commercial electricity in 2020. According to this goal, "13th Five-Year" period, the direct purchase of electricity will be in accordance with the size of more than $65 \%$ of the average annual growth rate of expansion. Therefore, the direct purchase of large consumers is still the mainstream form of electricity sales business at present and in the future for a period of competitive trading power.

According to the "on promoting the sale side reform implementation opinions", clearly put forward the social capital to open a business of selling electricity. Many ways to cultivate the sale of electricity market competition, giving users more choice, to enhance the sale of electricity service quality and user level, marking China's traditional single mode of sale of electricity will be power grid corp break.

Therefore, placing the power business release will be the final direction of future reform of the electricity market, we must actively explore innovative business and trading way of the sale of electricity companies and other large state-owned enterprises in the new energy, organizational change, grasp the customer resources thoroughly, and take the initiative to explore the sale of electricity to the specific ways to carry out.

Literature Review. China began the reform of the power industry investment market began in 1985 when the reform of the country's main reason for the construction of a monopoly power plant alone. In order to attract investors to invest in power generation enterprise construction parties, under the policy guidance, the local government, the domestic large enterprises and many foreign investors have joined the ranks of investment. With the deepening of reform, in 2002, China began 
to reform the factory net separates the split the establishment of the national power company soon. In order to attract investors to invest in power generation enterprise construction parties, under the policy guidance, the local government, the domestic large enterprises and many foreign investors have joined the ranks of investment. With the deepening of reform, in 2002, China began to reform the factory net separates the split the establishment of the national power company soon. The main body of the electric power investment is becoming more and more diversified and scale. At the same time, China's power market competition mechanism has been further developed, but there are many problems. At present, the main body of investment tends to power enterprises, for power grid investment is little, due to the power grid in the electric power industry monopoly advantage, China's power generation enterprises in the development of the electric power industry is bound, it is difficult to have a further breakthrough hindered the overall efficiency of the power industry.

With the development of China's economy, the power grid construction and development speed is very fast, and the growing demand for funds, so the power grid investment is open, how to open has been the concern of all circles. In 2002 the State Council on the electric power system reform document No. 5 pointed out that "in the factory net separates the reorganization after allowing the power and power grid enterprises listing and financing through the capital market, to further implement the shareholding system reform, then began to emerge some private capital into the field of distribution network.

In March 15th this year, the CPC Central Committee, the State Council issued a number of opinions on further deepening the reform of the electric power system, the new electricity reform officially kicked off. At the same time, is also preparing to introduce a lot of supporting documents, the sale of electricity side system reform is one of them. The main purpose is to set up the sale of electricity companies, allowing private capital to enter. So, less than three months time, only Shenzhen, Shandong, Heilongjiang Province, there are more than ten enterprises in the industrial and commercial registration application for the sale of electricity business, but because of the specific details of the sale of electricity business documents have not yet introduced, these companies did not carry out the sale of electricity business.

\section{The SWOT Analysis of the Power Supply Company}

Compared to the previous public expectations, although it may not have to split the grid in the new scheme, scheduling independent hot content but the change of grid profit model will also lead to the power market situation has undergone profound changes.

The strategy of distribution network investment also increased the power grid enterprises to focus on economic benefits. For grid enterprise distribution network planning, the new electricity reform policy in the same time, it also brings opportunities. The SWOT will be used to model visual display.

Table 1 SWOT analysis model

\begin{tabular}{|c|l|l|}
\hline & \multicolumn{1}{|c|}{ superiority } & \multicolumn{1}{|c|}{ Weak } \\
\hline \multirow{5}{*}{ Opportunity } & $\begin{array}{l}\text { The company has a grid structure, } \\
\text { production and management system } \\
\text { more standardized, highly educated } \\
\text { management skills and high } \\
\text { maintenance personnel, several years } \\
\text { of operating experience, reliability and } \\
\text { power quality has safeguard system to } \\
\text { achieve their own enterprise base can } \\
\text { the emergence of intelligent } \\
\text { equipment, although the increase in } \\
\text { investment costs, but to facilitate the } \\
\text { maintenance of the day, in the long } \\
\text { run, it is bound to benefit the } \\
\text { enterprise's cost reduction and } \\
\text { service upgrade. }\end{array}$ \\
\hline \multirow{5}{*}{ threaten } & $\begin{array}{l}\text { The power supply company is a a } \\
\text { commitment to the power supply } \\
\text { reliability and power quality. In recent } \\
\text { years, the development of industrial }\end{array}$ & $\begin{array}{l}\text { As a state-owned monopoly } \\
\text { enterprises, the development of the } \\
\text { company by the policy of greater } \\
\text { impact on the operation of the }\end{array}$ \\
\hline
\end{tabular}




\begin{tabular}{|l|l|l|}
\hline & $\begin{array}{l}\text { load, application of new energy and } \\
\text { smart devices also brings the network } \\
\text { uncertainty sources more harmonious, } \\
\text { the security and stability of power grid } \\
\text { and power quality has brought new } \\
\text { challenges. }\end{array}$ & $\begin{array}{l}\text { system reform, the relative lack of } \\
\text { experience. In the new electricity } \\
\text { reform background, profit model is } \\
\text { no longer earn electricity generation } \\
\text { side, side of the post, but for Internet } \\
\text { access, how to find new profit point } \\
\text { is the huge challenge. }\end{array}$ \\
\hline
\end{tabular}

Path of the New Electric Power Sale Mode. Under the new electricity reform, the general direction of the new energy enterprise competitive strategy should give up the industry to follow the strategy take the lead strategy. With reference to the above SWOT analysis, the power supply company may wish to carry out more practice in the following areas.

Speed up the Construction of Capacity. Accelerate the construction of smart grid, the basic information and communication and smart grid data computing, and fully tap the value of large data resources, intelligent decision-making to complete the operation, thereby enhancing the level of intelligent power grid. Actively carry out the distributed power access services linked to multi energy complementary energy Internet building a variety of energy forms collaborative transformation of integrated energy network.

Enhance the Ability of Service Transformation. To carry out the fine service of different objects, improve the use of electricity efficiency, reduce the cost of electricity, and expand the potential incremental market. Improve user service capacity and demand side response capability. The sale of electricity services and business before the background separation, to improve the level and efficiency of the front desk, while the establishment of an efficient business support system to support the front desk, in order to enhance the core competitiveness. Actively expand the value-added services, according to the needs of users to provide a variety of value-added services.

Expand the Scope of Innovation and Development. Camp with the grid layout, the realization of "service network, a grid, people have their" management mode. Determine the county-level power supply enterprise level distribution network operation and marketing services business by the customer service center unified management, improve the efficiency of collaboration. Innovative business model according to the scale of historical data to financial investors and electricity consumers to provide better and more diversified power futures services.

Establish Customer Database. Trading platform built after the official separation of net sales, the power company is no longer directly facing the original marketing department received customers may be sold in the middle of the business and the power of the power companies. Through the establishment of archives to understand the power generation, the power of the situation, familiar with the operation of different customer models and habits for customers to put forward a better energy-saving distribution programs, improve service levels, enhance the image of the enterprise.

\section{Conclusion}

Power grid enterprises should give full play to their own advantages explore planning method considering uncertainty, multi game in the distribution network in the market Zhandexianji according to their own development needs, rational planning of the new project of distribution network, investment and construction.

One of the important goals of electric power regulation is to establish a perfect electric power market. A period of time, we focus on the resolution of the electric power industry, that can be established by splitting the market mechanism, and the construction of the electricity market is not necessarily the grid resolution, scheduling independent, key is to change the mechanism of power grid enterprise exclusive buy electricity to sell electricity, the supply and demand of trading at auction bidding way.

From the successful experience of reform of electric power industry of all countries, countries have strengthened the development of electric power industry regulation, the basic form of 
government macro management, supervision of market regulators, market participants fully developed industry system, industry associations timely service supervision. Therefore, the key effect of the reform inspection and supervision system mainly to see whether there is mature power market, both supply and demand to see whether the auction bidding way to deal directly, see the power grid enterprises alone buy unique selling pattern is broken. In a fair competitive environment, enterprise profit even in the government to strengthen the power grid impulse, without discrimination, fair and open and three scheduling under the supervision of power grid become more neutral high-speed road, the functions of scheduling, power will further optimize the allocation of resources in the market, so that the power companies focus on power grid construction and power grid this is the hallmark of safe operation, the existing power regulatory reform, is the next step in the path of reform.

China power market reform is a complex process, there are many controversial issues, such as the green scheduling or economic dispatch, power generation enterprises can directly participate in the sale of electricity market and so on, these are the development process of China power market since the establishment of the market economy in China, reflect the national condition, it is difficult to rely on international experience to solve. This requires not only the power of China's electricity regulatory authorities in the early market planning and power companies to work closely, but also in the whole process of electricity market reform and business, the academic community to work closely together. To achieve this goal, it needs to give full play to the role of social organization as a bridge between the government and the market outside the third sector.

\section{Acknowledgements}

This research is supported by "the Fundamental Research Funds for the Central Universities" (2014MS146)

\section{References}

[1] Huang Xiaorong, Hua Guochun. Study on the measures of state grid Sichuan electric power company to deal with the new electric power system reform, Jilin water resources. 2016.

[2] Chen Hongxia, Gao Yujing. The new power to change the "gate" trillion market ready. Entrepreneurs daily. 2016.

[3] Zhou Qingqing. Analysis and Countermeasures on the integration of coal and electricity generation enterprises under the new situation changed, Electric Business Herald. 2015.

[4] Wang Wei. The Path of China Electric Power Regulatory System Reform

under the New Round of Electricity Reform, Journal of the Party School of the Central Committeeof the C.P.C.2016.

[5] Shen Hongyu, Chen Jin, Gui Sanrong, Tan Jian, Wang Zhe, Li Yang. The influence and Countermeasures of the new round of electricity reform on the distribution network planning of power grid enterprises. 2016.

[6] Chen Xiaojing. Study on system of electric power regulation China. Zhengzhou University. 2002. 